\title{
Venom Protein
}

National Cancer Institute

\section{Source}

National Cancer Institute. Venom Protein. NCI Thesaurus. Code C106132.

Protein isolated from venom. 